\title{
Efficacy of Argentine propolis formulation for topical treatment of canine otitis externa
}

\author{
[Eficácia da formulação da propólis argentina para o tratamento tópico de otite externa canina] \\ L.A. Lozina $^{1}$, M.E. Peichoto ${ }^{1}$, S.I. Boehringer ${ }^{1}$, P. Koscinczuk ${ }^{1}$, G.E. Granero ${ }^{2}$, O.C. Acosta ${ }^{1}$ \\ ${ }^{1}$ Facultad de Ciencias Veterinarias - UNNE \\ Sargento Cabral 2139 (3400) \\ Corrientes, Argentina \\ ${ }^{2}$ Facultad de Ciencias Químicas - UNC - Córdoba, Argentina
}

\begin{abstract}
The therapeutic effects of Argentine propolis ear drop formulation on canine otitis externa were evaluated. Forty-eight dogs with symptoms of otitis externa were randomly assigned to double-blinded, controlled clinical trial to evaluate the efficacy of topical formulation with propolis versus a topical placebo in the treatment of otitis externa. The propolis preparation and placebo were administrated into both external ear canals, twice daily for 14 days. Throughout the study, clinical examination and microbiological analysis of dogs ear exudates were made. The most frequent microorganisms isolated in culture media were: Malassezia pachydermatis (54.2\%), Staphylococcus aureus (43.8\%), coagulasenegative Staphylococcus (25.0\%), Pseudomonas aeruginosa (20.8\%), Candida albicans (18.8\%), Proteus mirabilis (16.7\%), Streptococcus spp. (16.7\%), Enteroccocus faecalis (12.5\%), Escherichia coli (12.5\%), Staphylococcus intermedius (6.3\%), Klebsiella spp. (4.2\%), and Candida glabrata (2.1\%). Whereas the control group did not recover from the infectious ear disease, the propolis preparation exhibited antimicrobial activity against most of the microorganisms isolated from samples of the treated group. In addition, no propolis-adverse effects were observed. This allowed propolis-treated patients to show a significant improvement of the clinical parameters. Thus, this new Argentine propolis ear drop formulation may be used for topical treatment of otitis externa in dogs.
\end{abstract}

Keywords: dog, propolis, glicerin-propylenglycol, otitis externa

\section{RESUMO}

Os efeitos terapêuticos da formulação em gotas óticas de própolis procedentes da Argentina foram avaliados no tratamento da otite externa canina. Quarenta e oito cães com sintomas de otite externa foram distribuídos aleatoriamente em ensaio clínico duplo-cego controlado para avaliar a eficácia da formulação tópica com a própolis contra um placebo tópico no tratamento da otite externa. A preparação de própolis e placebo foi administrada em ambos os canais da orelha externa, duas vezes por dia, durante 14 dias. Ao longo do estudo, os cães foram submetidos a exame físico e à análise microbiológica de exsudatos auriculares. Os mais frequentes microrganismos isolados em meios de cultura foram: Malassezia pachydermatis (54,2\%), Staphylococcus aureus (43,8\%), Staphylococcus coagulase-negativo (25,0\%), Pseudomonas aeruginosa (20,8\%), Candida albicans (18,8\%), Proteus mirabilis (16,7\%), Streptococcus spp. (16,7\%), Enterococcus faecalis (12,5\%), Escherichia coli (12,5\%), Staphylococcus intermedius (6,3\%), Klebsiella spp. (4,2\%) e Candida glabrata (2,1\%). A preparação de própolis apresentou atividade antimicrobiana contra a maioria dos microrganismos isolados de amostras do grupo de tratamento, sendo que os do grupo-controle não se recuperaram da doença infecciosa auricular, e não foram observados efeitos adversos à própolis. Isso permitiu aos pacientes tratados com própolis melhora significativa dos parâmetros clínicos. Essa nova formulação da própolis argentina para o ouvido apresenta potencial utilidade no tratamento tópico da otite externa em cães.

Palavras-chave: cão, própolis, glicerina-propilenoglicol, otite externa

Recebido em 24 de dezembro de 2009

Aceito em 15 de outubro de 2010

E-mail: llozina@vet.unne.edu.ar 


\section{INTRODUCTION}

Otitis externa (OE), commonly referred to as an "ear infection", is a condition characterized by inflammation of the external ear canal. Ear infections represent one of the main reasons that dogs are presented to veterinarians, and may affect up to 20 percent of thems (Carlotti, 1991). Dogs with OE often present swelling and erythema of the epithelial tissue of the ear canal, increased discharge from the ceruminous glands in the ear, and behavior suggesting pain and pruritus (Gotthelf, 2004). Environmental factors such as high temperature and humidity can influence the incidence of OE in dogs (Carlotti, 1991).

Propolis is a resinous mixture of substances collected by honey bees (Apis mellifera) from various plant sources (Bankova et al., 2000). Its chemical composition is variable, and depends on its geographical origin; however, all propolis products present similar antimicrobial activity on Staphylococcus aureus and Escherichia coli, and antifungal activity on Candida albicans (Bankova et al., 1995; Kujumgiev et al., 1999). Several studies related to its antimicrobial activity have showed that Gram-positive bacteria are more susceptible to ethanolic extracts of propolis than Gram-negative bacteria (Kujumgiev et al., 1999; Fernandes Junior et al., 2006). Recently, it was demonstrated that propolis ethanolic extracts (PEE) from Argentina exhibited fungicidal effect on microorganisms isolated from ear exudates of dogs (Lozina et al., 2006).

Besides, some authors reported antiinflammatory and analgesic activity (De Campos et al., 1998, Bankova et al., 2000). These effects have been attributed to the presence of certain compounds such as phenolic acids and flavonoids (Bankova et al., 2000).

Due to its antimicrobial and anti-inflammatory actions, propolis may be used in the treatment of OE in dogs. Taking into account that a topically applied propolis product to treat this infectious disease is not yet commercially available as ear drops in Argentina, the aim of this work was to evaluate the therapeutic effects of a new Argentine propolis ear drop formulation in dogs with OE.

\section{MATERIAL AND METHODS}

Propolis was gathered from Apis mellifera beehives of Tunuyán (Mendoza, Argentina), and stored at $4^{\circ} \mathrm{C}$ in the dark. Organoleptic features and physicochemical properties were analyzed according to current Argentine standards (Normas..., 2008a,b). The content of total phenolic compounds was determined by the Folin-Ciocalteu method (Singleton et al., 1999). Results were expressed as gallic acid equivalents. The total flavonoid content was estimated using the method of Woisky and Salatino (1998). Concentrations were spectrophotometrically ascertained at $420 \mathrm{~nm}$ with quercetin as standard.

Propolis was ground to a fine powder and extracted with $80 \%$ ethanol by maceration and agitation under dark and at room temperature. After three days, it was frozen overnight to $20^{\circ} \mathrm{C}$, and then the mixture was centrifuged to obtain the supernatant, which was filtered through filter paper. This supernatant was dried by evaporation under vacuum at $40^{\circ} \mathrm{C}$ (Bankova et al., 1995), and the crude propolis ethanolic extract (PEE) was stored in dark at $4^{\circ} \mathrm{C}$ until use.

Ear drops were prepared using 2, 5\% PEE in a mixture of glycerin-propylenglycol (1:1). The placebo solution consisted of these two last compounds; with a colour index number of $19.140(0.07 \%$ p/v) (Farmacopea..., 1978) in order to obtain the same yellow colour of the propolis drops. Both formulations were packaged in dark glass eyedropper bottle and kept at room temperature $\left(25 \pm 5^{\circ} \mathrm{C}\right)$ until the development of treatments.

Forty-eight dogs of different breeds, both genders, aging from three months to 15 years old, presenting acute or subacute otitis externa (in progress for less than 30 days), were selected to be included in this study. These animals were randomly distributed into two groups. Thirtyeight out of the 48 dogs were allocated to the treatment group and only 10 dogs constituted the placebo control group. Each dog was considered as an individual case, and after examination and detailed revision of its auditory canals, it underwent treatment. The researchers and the owners were blinded to the type of solution administered until the end of the study. 
Dogs would be excluded from the trial if they had previously received topical or systemic treatment with antibiotic or antifungal, or steroidal and nonsteroidal anti-inflammatory drugs. They would also be excluded if concurrent auricular diseases such as ear parasites, foreign bodies, neoplasia, or hyperplasia of the meatus acusticus externus were present, and if they were gestating or suckling. Informed consent was obtained from the owners of all dogs prior to their participation in this study.

Placebo solution or propolis ear drops (0.25$1 \mathrm{~mL}$, depending on the size of the ear canal) were administered in both external ear canals of each animal, twice daily for 14 days. In order to ensure even distribution throughout the entire canal, immediately after application, the ears were massaged from 1 to $2 \mathrm{~min}$.

Exudates of both external auditory canals from all patients (propolis-treated and control) were obtained by means of sterile cotton swabs on day 0 (pre-treatment) and day 14 (treatment end). Two samples were obtained from each ear. One sample was transferred onto a culture transport media (Culturette, Eurotubo ${ }^{\circledR}$ ) and sent to the Bacteriology and Mycology Laboratory at the Faculdad de Ciencias Veterinarias (Universidad Nacional del Sudeste - Corrientes, Argentina) for microbial isolation and identification by standard methods; and the other was rolled onto glass slides for direct microscopic observation and cytological examination using Gram stain.

In order to isolate and identify microorganisms present in the samples, exudates were cultured on a variety of media under different incubation conditions (Chapman agar, MacConkey agar, Blood agar, Azida Blood agar, and Sabouraud agar with chloramphenicol). Identification of microorganisms was made using macro and microscope observation of the colonies and biochemical tests. While Gram-negative bacteria were identified by SIM (hydrogen-sulfide, indole, motility) test, citrate test, urease test, lactose fermentation in triple sugar iron (TSI) agar, and oxidase test for determination of nonfermentative bacillus (NFB); the Gram-positive bacteria were identified by coagulase test, esculin hydrolysis test, and methylene blue reduction test. In addition, for yeasts, special studies such as nutrition requirements, urease tests, and growth on rice medium were performed (Prado et al., 2008). Malassezia pachydermatis was microscopically identified by its morphology as well as by its ability to grow when subcultured on Sabouraud dextrose agar (medium without lipid supplementation). The identification of Candida spp. was based on phenotypic features, such as description of the macro- and micromorphology, auxanographic typing, and medium differential CHROM-agar Candida (Brito et al., 2007).

All dogs were examined by the clinician investigator on days 0 (D0), 7 (D7), and 14 (D14). In order to define an individual patient score, the following clinical parameters were evaluated by a single examiner: grade of inflammation, pruritus, and exudates of both external auditory canals. They were scored in a scale from 0 to 3 according to their intensity ( $0=$ none, 1 = mild, 2 = moderate, $3=$ severe). The scores for these three parameters were summed so that the highest possible clinical score was 9.

The efficacy of treatment was evaluated by two separate ways: clinical signs and microbiological findings. A successful clinical response was defined as a return to normal of all parameters (score $=0$ ). In addition, clinical improvement based on owner information was taken into consideration. A response of failure was assigned to patients for which the OE had not improved or had worsened, or for which additional antimicrobials were required. Successful microbiological response at the patient level included eradication of all baseline pathogens.

The results were analyzed and described by way of frequency and percentual distribution expressed in tables and graph charts. Differences between propolis-treated and control groups were compared using one-way analysis of variance (ANOVA) followed by Tukey's test. Statistical analyses were performed using the software InfoStat/Professional, version 1.1. A value of $\mathrm{P} \leq 0.05$ indicated statistical significance.

\section{RESULTS}

Quality control analysis of raw propolis and its ethanolic extract met physical, chemical, and sensory requirements standard according to Argentine rules (yield of $20.6 \pm 0.4 \mathrm{~g} / 100 \mathrm{~g}$ of propolis, oxidation rate of $2 \mathrm{sec}$, flavonoid content of $10.7 \pm 0.1 \mathrm{mg} / \mathrm{g}$ of propolis, and 
phenolic compounds of $208.6 \pm 2.8 \mathrm{mg} / \mathrm{g}$ of propolis).

The PEE was adequately dissolved in the vehicle used for the otic formulation used in this study. After its administration, the viscosity of this formulation improved its permanency in the external auditory canal of dogs, even after head shaking of some of the sick animals.

Of the 48 dogs diagnosed with OE and included in this study, 36 were males (75\%) and 12 were females (25\%), Eight patients (16.7\%) aged from 0 to 2-year-old, 16 (33.3\%) from 2 to 5-year-old, and 24 (50\%) were over 5-year-old. Dogs with pendulous ears represented $68.4 \%$ of the total affected. Taking into account the breeds, the percentage distribution was: Mongrels (20.8\%), Cocker Spaniels (20.8\%), German Shepherd (18.8\%), Boxer (8.3\%), and others, according to Figure 1.

All dogs under assays completed the two-week protocol. No adverse drug effects were observed. At the beginning of the study, discomfort disease was evident in all the dogs, and it was accompanied by pruritus, abnormal exudation, erythema, pain and/or head shaking. On D7 and D14, clinical signs of otitis were less significative in the treated dogs than in the control dogs. The dogs belonging to the control group did not recover from the infectious ear disease (Figure 2).

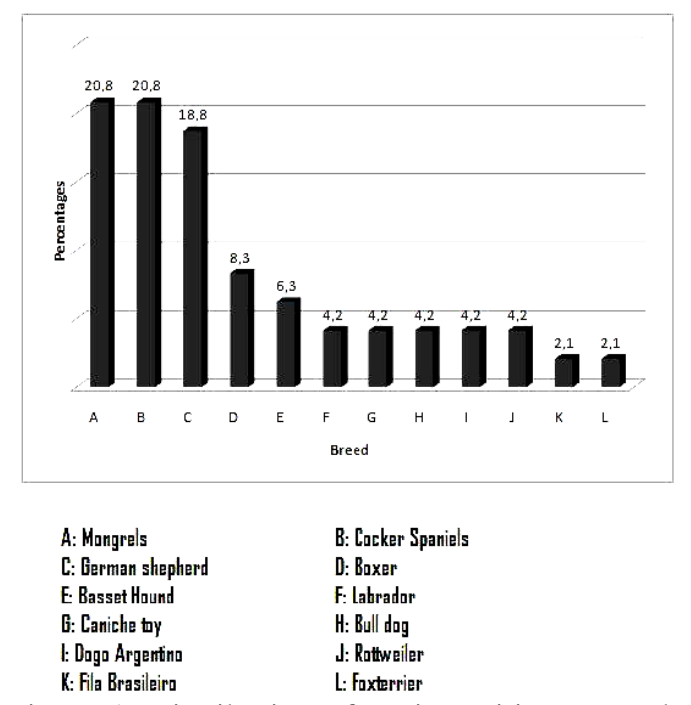

Figure 1. Distribution of canine otitis externa by breed.

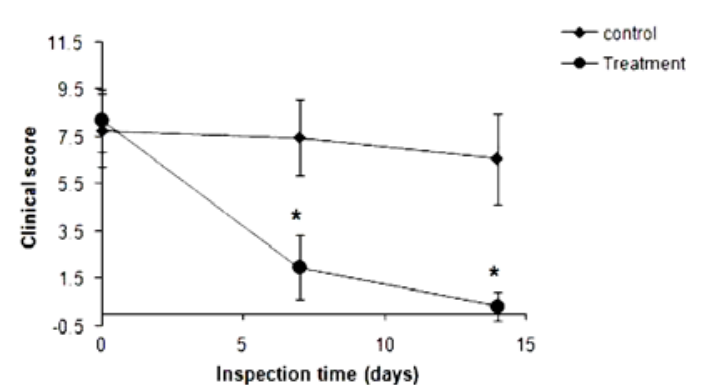

Figure 2. Comparison of clinical scores of dogs belonging to propolis-treated or control group on D0, D7, and D14. Error bars indicate the mean \pm the standard deviation. Asterisks indicate significant differences between treatment and control $(\mathrm{P}<0.05)$.

Microbiological culture revealed that $81.6 \%$ of the ear infections corresponded to mixed bacterial and fungal infection, $13.2 \%$ to bacterial infection, and $5.2 \%$ to fungal infection. The most common isolated bacteria were: Staphylococcus aureus, coagulase-negative Staphylococcus, Pseudomonas aeruginosa, Proteus mirabilis, Streptococcus spp., Enteroccocus faecalis, Escherichia coli, Staphylococcus intermedius, and Klebsiella spp. Among the mycotic microorganisms, Malassezia pachydermatis, Candida albicans, and Candida glabrata were the most frequently isolated (Figure 3). After treatment (D14), the control dogs showed the same microorganisms isolated on D0, whereas the treated dogs showed different results depending on the etiological microorganism isolated. About the yeasts, M. pachydermatis and C. glabrata were $100 \%$ sensitive to the propolis formulation, whereas C. albicans was $75 \%$ sensitive.

Propolis formulation exhibited potent antibacterial activity, particularly against Grampositive bacteria. Staphylococcus aureus, Streptococcus spp., E. faecalis (formerly known as beta-hemolytic group D Streptococcus), and coagulase-negative Staphylococcus were the most sensitive microorganisms. Gram-negative bacteria, such as Klebsiella spp., E. coli, $P$. aeruginosa, and $P$. mirabilis were sensitive to the treatment with the propolis formulation but less than Gram-positive bacteria (Table 1). 


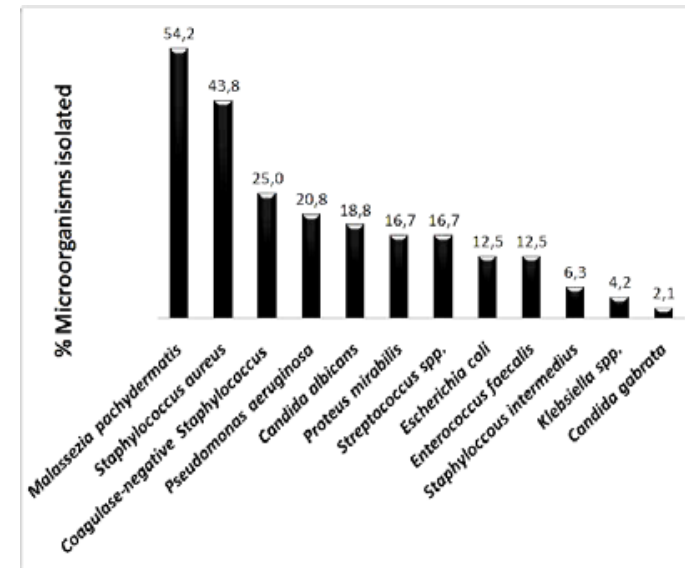

Figure 3. Percentual distribution of microorganisms isolated from the ears of 48 dogs with otitis externa.
Of the 38 dogs treated with propolis, 27 (71\%) responded satisfactorily (i.e. cured or clearly improved, both clinical and microbiologically). The remaining 11 dogs (29\%) did not respond to the treatment; thus, they had to receive the appropriate therapy after the trials.

Treatment efficacy resulted in a statistically significance between groups on D7 ( $\mathrm{X}-0.05)$ and $\mathrm{D} 14$, when decrease of inflammation, amount of discharge, and pruritus were evident. Although not all the propolis-treated dogs were cured at the end of the present study, significant improvement of the clinical parameters were evident in all cases on D7 and D14.

Table 1. Percentage susceptibility to the propolis formulation of microorganisms isolated from external ear canals of dogs with otitis externa after 14 days of treatment

\begin{tabular}{|c|c|c|c|c|c|}
\hline \multicolumn{3}{|c|}{ Control group $(n=10)$} & \multicolumn{3}{|c|}{ Treatment group $(\mathrm{n}=38)$} \\
\hline $\begin{array}{l}\text { Microorganism } \\
\text { isolated }\end{array}$ & $\begin{array}{l}\text { Number } \\
\text { of cases }\end{array}$ & $\begin{array}{l}\text { Percentage of } \\
\text { sensitivity of } \\
\text { isolated } \\
\text { microorganism }\end{array}$ & $\begin{array}{l}\text { Microorganism } \\
\text { isolated }\end{array}$ & $\begin{array}{l}\text { Number } \\
\text { of cases }\end{array}$ & $\begin{array}{c}\text { Percentage of } \\
\text { sensitivity of isolated } \\
\text { microorganism }\end{array}$ \\
\hline $\begin{array}{l}\text { Malassezia } \\
\text { pachydermatis }\end{array}$ & 3 & + & $\begin{array}{l}\text { Malassezia } \\
\text { pachydermatis }\end{array}$ & 23 & 100 \\
\hline $\begin{array}{l}\text { Staphylococcus } \\
\text { aureus }\end{array}$ & 3 & + & $\begin{array}{l}\text { Candida } \\
\text { albicans }\end{array}$ & 9 & 75 \\
\hline $\begin{array}{l}\text { Staphylococcus } \\
\text { intermedius }\end{array}$ & 3 & + & $\begin{array}{l}\text { Candida } \\
\text { glabrata }\end{array}$ & 1 & 100 \\
\hline $\begin{array}{l}\text { Escherichia } \\
\text { coli }\end{array}$ & 1 & + & $\begin{array}{l}\text { Staphylococcus } \\
\text { aureus }\end{array}$ & 18 & 94 \\
\hline $\begin{array}{l}\text { Pseudomonas } \\
\text { aeruginosa }\end{array}$ & 1 & + & $\begin{array}{l}\text { Coagulase- } \\
\text { negative } \\
\text { Staphylococcus }\end{array}$ & 12 & 70 \\
\hline \multirow[t]{3}{*}{$\begin{array}{l}\text { Candida } \\
\text { albicans }\end{array}$} & 1 & + & $\begin{array}{l}\text { Proteus } \\
\text { mirabilis }\end{array}$ & 8 & 25 \\
\hline & & & $\begin{array}{l}\text { Enterococcus } \\
\text { faecalis }\end{array}$ & 6 & 83 \\
\hline & & & Klebsiella spp & 2 & 100 \\
\hline
\end{tabular}

+ On day 14, the same organisms initially isolated in the ten cases were identified. 


\section{DISCUSSION}

It is well known that topical treatment is the method of choice for treating $\mathrm{OE}$ since antimicrobial agents come into direct contact with the pathogens (Rougier et al., 2005). For this reason, a topical preparation with propolis was used in this work, and the results suggest that it provides an effective and well tolerated option for the medical management of $\mathrm{OE}$ in dogs.

Propolis is particularly a rich source of phenolic compounds with biological activities (Quiroga et al., 2006). Different types of propolis exist naturally, which differ in their chemical composition according to their botanical origin (Bankova et al., 2000). In previous works, the authors analyzed propolis samples from different regions of Argentina, and the from Mendoza, where Populus spp. is the most abundant vegetation, having the highest phenolic and flavonoid contents (Lozina et al., 2010); for this reason, this sample was used in the preparation of the ears drops used in this study.

Propolis is a non-toxic resinous or present low toxicity (Quiroga et al., 2006). However, Marques Senedese et al. (2008) showed that a topical formulation used for the treatment of burns and containing different concentrations of Brazilian propolis (1.2, 2.4, and 3.6\%) had no mutagenic effect in either in vitro or in vivo system, but $3.6 \%$ propolis gel was found to be cytotoxic in the in vitro systems. For this reason, 2, 5\% PEE was used in this study.

$\mathrm{OE}$ is one of the most commonly disease affecting dogs from different genders, age, and breed. It was observed that males were more susceptible to $\mathrm{OE}$ than females. On the other hand, Fernandes Junior et al. (2006) reported $58 \%$ affection in females and $42 \%$ in males. However, some authors state that gender predisposition is nonexistent (August, 1988; Carlotti, 1991). About the age, it was observed that $50 \%$ of the affected dogs were older than 5year, which is in accordance with previous reports (August, 1988; Carlotti, 1991).

Mongrel and Cocker Spaniel dogs were the most affected breeds in this work. Angus et al. (2002) observed, by histological examination of the ear canal tissue, that the sensibility of Cocker
Spaniels for OE could be related to the exacerbated tissue response when inflammatory processes are present. In addition, a large number of ceruminous glands were also observed (Kowalski, 1988). Hyperactivity of the ceruminous glands has been demonstrated in German Shepherd dogs, a breed which is also highly susceptible to OE (August, 1988; Kowalski, 1988).

Whereas $M$. pachydermatis was the most commonly isolated fungal pathogen, Candida spp. was only occasionally isolated from exudates of dogs with OE, which is consistent with other reports (Kiss et al., 1997). In addition, in most of the analyzed samples, $M$. pachydermatis was associated with $S$. aureus, confirming the symbiosis between these two microorganisms (Kowalsky, 1988; Rougier et al., 2005).

Staphylococcus spp. was the most commonly isolated bacterium, which is in accordance with previous reports (Kiss et al., 1997). The distribution presented in this work, was Staphylococcus aureus (43.8\%), coagulasenegative Staphylococcus (25.0\%), and Staphylococcus intermedius (6.3\%); being Staphylococcus aureus the most frequent of the genus the Staphylococcus (Kiss et al., 1997; Perez Tort et al., 2000). On the other hand, Lilenbaum et al. (2000) reported coagulasenegative Staphylococcus as the most commonly isolated bacteria from ear exudates of dogs with $\mathrm{OE}$.

In this work, $P$. aeruginosa, Proteus spp., and $E$. coli were also identified in diseased ears, but in fewer numbers. The rare isolation of $P$. aeruginosa and $P$. mirabilis is not in accordance with others authors (Kowalski, 1988; Foster and Deboer, 1998).

All dogs showed the same clinical signs described in other similar studies (Fernandes Junior et al., 2006). Only, in those cases in which the secretion was abundant and represented a discomfort for the dog and the owner, excess exudates and remnant of the otic preparation was retired from ear flap with a cotton soaked in solution saline, avoiding the solutions of clean entering the canal ears, since coinciding with other researchers as Mansfield et al. (1990), who reported over growth yeast when using saline 
solution. It was considerated that any cleaning action could interfere with the results.

All isolated yeasts were highly sensitive to propolis formulation used in this study, which is in accordance with in vitro studies, in which a PEE was used (Lozina et al., 2006). Grampositive bacteria were also highly susceptible to this formulation. However, Gram-negative bacteria were the most resistant microorganisms. This observation is consistent with a previous in vitro study (Sforcin et al., 2000). At present, the causes of decreased activity of propolis extract on Gram-negative bacteria are poorly understood. One possible explanation is that the cell wall of these bacteria is more complex and with a higher lipid content than that of Grampositive bacteria (Sforcin et al., 2000).

Eleven out of the 38 propolis-treated dogs did not respond to the therapy. They corresponded to mixed bacterial and fungal infection associated with Proteus mirabilis $(\mathrm{n}=6)$ and $P$. aeruginosa $(n=5)$. It is perfectly known that eradication of these Gram-negative bacteria from the infection site is not an easy task. They are even resistant to commonly used antimicrobials such as quinolones and aminoglycosides (Vargas et al., 2004). However, four from the nine cases in which $P$. aeruginosa was isolated showed sensitivity to the propolis preparation. Different in vitro studies have already shown that $P$. aeruginosa could be sensitive to a higher concentration of propolis (Sforcin et al., 2000).

In conclusion, these findings confirm the interest to develop an ear topical formulation of propolis as a promising new therapy for the treatment of OE in dogs, mainly if it is taken into account that this formulation has a wide antimicrobiological spectrum, anti-inflammatory effects, as well as to being a natural and not an expensive product. Thus, the new Argentine propolis ear drop formulation used in the present study may be useful in the treatment of canine OE.

\section{ACKNOWLEDGMENTS}

L. Lozina is the recipient of a cofinanced fellowship from the Consejo Nacional de Investigaciones Científicas y Tecnológicas and Universidad Nacional del Nordeste, Argentina. This work was carried out in partial fulfillment of the requirements for the $\mathrm{PhD}$ degree for $\mathrm{L}$. Lozina at the Universidad Nacional de Córdoba, Argentina.

\section{REFERENCES}

ANGUS, J.C.; LICHTENSTEIGER, C.; CAMPBELL, K.L. et al. Breed variations in histopathologic features of chronic severe otitis externa in dogs: 80 cases (1995-2001). J. Am. Vet. Med. Assoc., v.221, p.1000-1006, 2002.

AUGUST, J.R. Otitis externa: A disease of multifactorial etiology. Vet. Clin. N. Am.: Small Anim. Pract., v.18, p.731-742, 1988.

BANKOVA, V.; CHRISTOV, R.; KUJUMGIEV, A. et al. Chemical composition and antibacterial activity of Brazilian propolis. $Z$. Naturfors., v.50, p.167-172, 1995.

BANKOVA, V.; DE CASTRO, S.L.; MARCUCCI, M.C. Propolis: recent advances in chemistry and plant origin. Apidologie, v.31, p.3$15,2000$.

BRITO, E.H.S.; FONTENELE, R.O.S.; BRILHANTE, R.S.N. et al. Phenotypic characterization and in vitro antifungal sensitivity of Candida spp. and Malassezia pachydermatis strains from dogs. Vet. J., v.174, p.147-153, 2007.

CAMPOS, R.O.; PAULINO, N; DA SILVA, C.H. et al. Anti-hiperalgesic effect of an ethanolic extract of propolis in mice and rats. $J$. Pharm. Pharmacol., v.50, p.1187-1193, 1998.

CARLOTTI, D.N. Diagnosis and medical treatment of otitis externa in dogs and cats. $J$. Small Anim. Pract., v.32, p.394-400, 1991

FARMACOPEA NACIONAL ARGENTINA (FNA). Codex Medicamentarius Argentino. 7.ed. Buenos Aires, Argentina: Editorial Codex, 1978.

FERNANDES JÚNIOR, A.; LOPES, M.M.R.; COLOMBARI, $\mathrm{V}$. et al. Atividade antimicrobiana de própolis de Apis mellifera obtidas em três regiões do Brasil. Cienc. Rural, v.36, p.294-297, 2006.

FOSTER, A.P.; DEBOER, D.J. The role of Pseudomonas in canine ear disease. Compend. Contin. Educ. Vet., v.20, p.909-918, 1998.

GOTTHELF, L.N. Diagnosis and treatment of otitis media in dogs and cats. Vet. Clin. North Am. Small Anim. Pract., v.34, p.469-487, 2004 
KISS, G.; RADVANYI, S.; SZIGETI, G. New combination for the therapy of canine otitis externa. I- Microbiology of otitis externa. $J$. Small Anim. Pract., v.38, p.51-56, 1997.

KOWALSKI, J.J. The microbial environment of the ear canal in health and disease. Vet. Clin. North Am. Small Anim. Pract., v.18, p.743-754, 1988.

KUJUMGIEV, A.; TSVETKOVA, I.; SERKEDJIEVA, Y. et al. Antibacterial, antifungal and antiviral activity of propolis of different geographic origin. J. Ethnopharmacol., v.64, p.235-240, 1999.

LILENBAUM, W.; VERAS, M.; BLUM, E. et al. Antimicrobial susceptibility of staphylococci isolated from otitis externa in dogs. Lett. Appl. Microbiol., v.31, p.42-45, 2000.

LOZINA, L.A.; BOEHRINGER, S.; DAQUINO, M. et al. Eficacia del propóleos sobre Malassezia pachydermatis, correlación de distintas técnicas in vitro. Acta Farm. Bonaerense, v.25, p.560563, 2006.

LOZINA, L.A.; PEICHOTO, M.E.; ACOSTA, O.C. et al. Estandarización y caracterización organoléptica y físico-química de 15 propóleos argentinos. Lat. Am. J. Pharm., v.29, p.102-110, 2010.

MANSFILED, P.D.; BOOSINGER, T.R.; ATTLEBERGER, M.H. Infectivity of Malassezia pachydermatis in the external ear canal of dogs. J. Am. Anim. Hosp. Assoc., v.26, p.97-100, 1990.

MARQUES SENEDESE, J.; RODRIGUES, A.R.; ANDRADE FURTADO, $M$. et al. Assessment of the mutagenic activity of extracts of Brazilian propolis in topical pharmaceutical formulations on mammalian cells in vitro and in vivo. eCAM Advance Access published, DOI 10.1093/ecam/nen049, 2008.

Normas IRAM-INTA 15935-1. Productos del Noroeste Argentino. Parte 1: Propóleos en bruto. Primera Edición, 2008a.
Normas IRAM-INTA 15935-2. Productos del Noroeste Argentino. Parte 2: Extractos de propóleos. Primera Edición, 2008b.

PÉREZ TORT, G.; SIGAL ESCALADA, G.; MARTINO, G. et al. Eficacia Terapéutica del gel ótico plus en el tratamiento integral de las otitis externas de los caninos. Bol. Tec. Vetanco, v.15, p.2-3, 2000.

PRADO, M.; BRILHANTE, R.S.N.; CORDEIRO, R.A. et al. Frequency of yeasts and dermatophytes from healthy and diseased dogs. J. Vet. Diagn. Invest., v.20, p.197-202, 2008.

ROUGIER, S.; BORELL, D.; PHEULPIN, S. et al. A comparative study of two antimicrobial/anti-inflammatory formulations in the treatment of canine otitis externa. Vet. Dermatol., v.16, p.299-307, 2005.

QUIROGA, E.N.; $\quad$ SAMPIETRO, D.A.;SOBERON,J.R. et al. Propolis from northwest of Argentina as a source of antifungal principles. J. Appl. Microbiol., v.101, p.103-110, 2006.

SINGLETON, V.L.; ORTHOFER, R.; LAMUELA-RAVENTOS, R.M. Analysis of total phenols and other oxidation substrates and antioxidants by means of Folin Ciocalteu reagent. Methods Enzymol., v.299, p.152-78, 1999.

SFORCIN, J.M.; FERNANDES, A.; LOPES, C.A. et al. Seasonal effect on Brazilian propolis antibacterial activity. J. Ethnopharmacol., v.73, p.243-49, 2000.

VARGAS, A.C.; LOGUERCIO, A.P.; WITT, N.N. et al. Atividade antimicrobiana "in vitro" de extrato alcoólico de própolis. Cienc. Rural, v.34, p.159-163, 2004.

WOISKY, R.; SALATINO, A. Analysis of propolis: some parameters and procedures for chemical quality control. J. Apic. Res., v.37, p.99-105, 1998. 